\title{
ANARCHISM VS. MARXISM IN THE RUSSIAN REVOLUTION A REVIEW OF RECENT LITERATURE
}

I.

One of the most devastated battlefields of the last century is the shifting, ideological war zone within which the proponents of anarchism and Marxism have waged their struggle. It has been the scene of fierce combat in a battle involving the loss of many lives. Although the origins of this confrontation can be charted clearly back as far as the 1872 Hague congress of the first International, it is quite evident from several recent publications that both sides are continuing the hostilities. Furthermore, it is also true that the problems which have been raised in the course of the conflict have remained unresolved. These problems reach to the heart of some of the most fundamental issues of revolutionary transformation which have concerned the Western world; for this reason, their exposition in the books under review here explicitly call out for our attention, analysis and judgment.

In the same year (1974), two anarchist classics have been published in this country by Solidarity Press, ${ }^{*}$ while in Moscow Mysl' press has issued a thorough scholarly study of the Bolshevik struggle against anarchism during the Russian Revolution. Voline's The Unknown Revolution was originally published in French in 1947 (re-issued, 1969) and was republished in Holly Cantine's English translation by Freedom Press in London in 1955. The present English translation incorporates the earlier one with the addition of sections newly translated by Fredy Perlman which had been omitted in the Freedom Press edition. Solidarity's edition of Peter Arshinov's History of the Makhnovist Movement, 1918-1921, translated from the Russian by Lorraine and Fredy Perlman, is the first English publication of this work, which appeared originally in Berlin in 1923. In addition to the complete text, the volume contains a number of documents from Makhno's movement which also appear in English for the first time (with the exception of three of the documents which coincidentally appeared the year before in P. Avrich (ed.), The Anarchists in the Russian Revolution, published by Cornell University Press). Solidarity's intentions in publishing these works are explicitly partisan, as the preface by the press makes clear. The Soviet work, Oktiabr'skaia revoliutsiia $i$ krakh anarkhizma (The October Revolution and the Failure of Anarchism) is by the historian S. N. Kanev. The importance the Soviet authorities have attached to this book is evidenced by the comparatively large tirage permitted $(7,000$ copies issued), the costly durable binding (rare), and the imprint of one of the most prestigious publishing houses in the USSR, sponsored in this instance by one of the agencies of the Central Committee of the Communist Party. Let us consider the books chronologically in order of publication in an effort to examine the nature of the ideological war in which they are engaged.

The insurrectionary movement led by Nestor Makhno between 1918 and 1921, one of the central episodes of the immediate post-revolutionary years in Bolshevik Russia, has been the subject of vastly varied and conflicting interpretations. Peter Arshinov, one of the Makhnovist activists, never really was able to complete the history of the movement that he had intended. He began the work on four separate occasions, and each time the manuscript and many of the 
documents he had collected were lost, seized or destroyed amidst the turmoil of the Russian civil war. Nevertheless, the book he finally finished in Moscow in 1921 under difficult circumstances remains the most comprehensive source for any examination of the Makhnovist movement.

Arshinov was clearly sympathetic to the movement, but this has not prevented him from exercising criticism in his analysis. Voline believed that Arshinov was the most able person to write about Makhno because of his personal association with the insurgent leader, because of Arshinov's working class origins, and his exceptional knowledge about the broader aspects of the movement as a result of his large collection of documents on the Makhnovists. It should also be noted that Arshinov began his political career as a member of a local Bolshevik party organization before turning to the anarchists after the collapse of the 1905 revolution; this initial experience provided Arshinov with a direct knowledge of the inner dynamics of both Bolshevism and anarchism which was shared by few revolutionaries.

The Makhnovshchina, as the movement is called in Russian, was "a colossal event" in Arshinov's opinion (p. 25). The singular signiticance that he saw in this movement revolves around the anarchist perspective of social revolution, decentralization, and mass movements emerging spontaneously from below, seeking to crush all external, hierarchical authority. He believed that no revolution in history had ever been "carried out by the working people in their own interests:" each time, "leaders, ideologists and organizers" had assumed direction and control over the people, thereby sabotaging the revolution and dooming it to "reenslavement" under the oppression of state systems and privileged ruling classes. In the case of Russia, the earlier failures in 1789. 1848 and 1871 were repeated with the conquest of power by Bolshevism. Prophetically, Arshinov predicted in 1921 (when non-Bolshevik groups still functioned) that "all the disagreements between the rival factions of [Soviet] democracy will disappear, and the entire democracy will carry on under the guidance of the unified Communist party" (p. 36). The Makhnovshchina was, in his view, the most heroic effort in Russia to resist Bolshevik control in the name of the "true revolution:" this meant the achievement of the "social revolution" against all authority rather than the "political revolution," a mere seizure of power from above in the anarchist view.

The critique of Bolshevism. which occupies the first four chapters of the book, is central to Arshinov's interpretation of the Makhnow'shchina. His thesis is that Bolshevism sought power, not a revolution. All serious revolutionary efforts were suppressed. frequently with unnecessary violence. The real revolution consisted of the mass movements at local levels seeking to control their own destinies. Arshinov's vision of the masses is that of a revolutionary anthropologist: peasants and workers are depicted tribally as having behavior and goals natural to them and completely apart from the rational and artificial solutions imposed from above by party functionaries and ideological leaders.

The movement itself began, according to Arshinov, not as a protest against Bolshevism but as a resistance movement against the German and Austrian forces who occupied the Ukraine in the summer of 1918 as a result of the Treaty of Brest-Litovsk. Isolated guerrilla actions grew "spontaneously" into a vast peasant movement over which Makhno. a peasant from the Ukrainian area in upheaval, assumed military leadership. As the movement gained support and won victories, it acquired territory and began a new administration of society based on anarchist principles. For 
six months between November 1918 and June 1919, the population in the region around Gulyai Polye, Makhno's native village, "lived without any external political authority," creating free communes of workers and peasants (p. 85).

This situation was interrupted by the armed invasion of the monarchist White Army under General Denikin early in 1918. Makhno was asked by the Bolsheviks to join the Red Army in order to defeat the counterrevolutionary army. Conditions were demanded for this union by Makhno, which involved guaranteeing the autonomy and internal organization of the insurgent forces. Both sides mistrusted one another ideologically but maintained unity long enough to defeat Denikin. In the summer of 1919, the Red Army under Trotsky began an invasion of the area held by Makhno's forces after Makhno refused Trotsky's order to disband his army. Trotsky's order to liquidate Makhno's army, and Arshinov's criticism of that order, is one of the clearest examples of the clash of ideologies, and the chasm separating them. This was the beginning of the end, though circumstances were such that the drama took two more years to play itself out. A renewed offensive by Denikin created another alliance between the Red Army and Makhno's forces. During the fall of 1919, Makhno led a brilliant military campaign against the White armies, establishing at the same time new anarchist centers in Aleksandrovsk and Ekaterinoslav, which grew increasingly anti-Bolshevik.

Arshinov considers the October 1919 regional congress of peasants and workers at Aleksandrovsk the highpoint of the Makhnovshchina. Two hundred delegates enthusiastically proclaimed the idea of free soviets in a stateless and egalitarian society. Arshinov's language in describing this congress is positively lyrical: "[The congress] remained engraved forever on the memories of many, if not all, as a beautiful dream about a life in which true liberty would bring people together, giving them the opportunity to live united at heart, joined by a feeling of love and brotherhood" (p. 150).

Aleksandrovsk and Ekaterinoslav in 1919 brought into existence the institutions of the anarchist social revolution, according to Arshinov. Prisons were evacuated, autonomous councils set up. factory managers dismissed, and freedoms of speech and assembly were enacted permitting a full range of propaganda and analysis; "in the course of the whole Russian revolution, [this] was the only period in which the freedom of the working masses found full expression" (p. 155). All of this "creative work" was abruptly interrupted in January 1920 by the renewal of the "violent struggle between the Makhnovists and the communist power" (p. 164). Arshinov admits it was a "merciless struggle on both sides," but his interpretation presents the Makhnovists fighting a defensive war against superior forces, far better organized, and willing to commit any atrocity to achieve the destruction of the anarchist threat. According to what Arshinov calls "moderate estimates," 200,000 people were shot or seriously injured by the Red Army in this campaign. (There are no available Soviet figures). In contrast to the indiscriminate killing by the Bolshevik forces, Makhno's army distinguished between the "party aristocracy" and Red Army leaders (who were killed) on the one hand, and the rank-and-file soldiers on the other, where "great restraint" was shown. Or so Arshinov would have us believe. This is an example of an ideological point that he was making about the Makhno forces; statistics cannot verify exactly how consistently this distinction was practiced. 
There was one final interlude of peace when Frunze, the Red Army commander of the Southern Front, negotiated with Makhno for support against another White Army campaign led by Wrangel (who had succeeded Denikin) in the fall of 1920 (see pp. 177-180 for the relevant document). This ended when Frunze ordered Makhno to disband his army after Wrangel's defeat. Arshinov says this was a request for "the Makhnovshchina to commit suicide" (p. 193). Makhno refused, and the last assault ensued. He held out until the summer of 1921 when his army was overrun and he escaped abroad.

At the end of his book, Arshinov tried to analyze the reasons for the failure of the Makhnovshchina. He criticized Makhno for his lack of theoretical knowledge, his carelessness in certain military situations, but basically found him to be a man of heroic stature. He turned his major criticism against the Bolsheviks, whom he describes as unscrupulous competitors for power. By monopolizing the press, the masses outside the Ukraine were prevented from knowing the truth about Makhno's movement. (This, incidentally, is disputed by Kanev's book, discussed below). He also blamed the theoretically-oriented anarchist intellectuals who, by and large, stood apart from this "practical" expression of anarchism: he chides them (unnamed) for "sleeping through a mass movement of paramount importance" (p. 242). Finally, he recognizes the "disease of disorganization" which has plagued anarchism, and urges all anarchists to organize themselves and to "go to the masses and merge with them" (pp. 244-245). Anarchists did not miss this reference to Bakunin, who had called revolutionaries in Russia to "fuse with the people" a half century before.

There are other problems which Arshinov does not elaborate on. Violence is acceptable and defensive for anarchists but is aggressive and inhumane when undertaken by Bolsheviks. Was the difference always so clear cut? The problem of leadership is crucial: Makhno's leadership genius is celebrated to the point where one might begin to speak of an anarchist "cult of personality," though anarchism is dedicated to the abolition of leaders at all levels (see especially pp. 50, 135, 165, 224). Arshinov is aware of the problems of taking responsibility for social change, but still removes the Makhnovists from the consequences of this responsibility on certain occasions in the interests of maintaining ideological consistency on the question of authority (p. 152). Finally, there are the related questions of popular support and constituency: if the Makhno forces were primarily peasant and rural (p. 97), it may mean that they lacked support among the urban workers who looked to the appeals of Bolshevism. What are the ramifications of this division?

II.

At the close of his preface to Arshinov's book, Voline says: "to be an anarchist is not obligatory. But it is necessary to know anarchism." One of the most informed sources for a reader to "know anarchism" is his massive 700 page Unknown Revolution. The scope is far wider than in Arshinov's book; indeed, Voline's work may be read properly in tandem with Trotsky's History of the Russian Rerolution. Like Trotsky's book, it is a memoir history, a personal account by a participant, with a particular ideological perspective. Voline's title refers to the fact that the essence of the Russian revolution remains a mystery to the world. The truth about 1917 lies in 
its hidden or unknown aspects, the ignored episodes, and the elements which have been distorted by bias or deliberately falsified. He makes the questionable assumption that he has "complete objectivity" to relate and interpret these aspects because he is an anarchist rather than a member of a political party with a vested interest in acquiring power. This point aside, however, Voline does probe into the elements of the revolution which have not been emphasized by Soviet historians, and which had been unknown in the West for many years when Voline was writing.

Voline might be called a "radical experientialist" because of his argument that people create revolutions not as a result of ideology or posited "laws" of economic crisis, but as a function of their concrete, personal experience of injustice and oppression. The Russian people, he writes, had to "live through" horrors like Bloody Sunday in 1905 "to understand the real nature of tsarism;" no amount of propaganda and theorizing could have galvanized the masses more than "living through [this] tangible and extensive historical experience" (p. 87). 1905 and also February 1917 are for Voline examples of the spontaneous process of mass upheaval, undirected by middle class intellectuals and party leaders. The "inevitability" of revolution arises as a climax to years of relentiess exposure of the people to this oppression, which heightens the "consciousness of the masses" to the point where "a violent and decisive revolution" is the last and desperate exit from the impasse (p. 136-7). The language is somewhat Leninist, but Voline's meaning behind these quoted passages is diametrically opposite to the Marxist conception of revolution where collective experience is overcome by elitist party authority and the "iron laws" of history.

Voline's history of the Russian revolution is dominated by his interpretation of the "two conceptions of social revolution," and it is here that the ideological confrontation is made explicit. He counterposes "power" and "administration." The former is not a force in itself but rather assumes concrete form only when based on a class, institution, political party or some other controlling organ. The latter is a natural and normal function in society and does not rely on police, parties or armies for enforcement. Administrators are organizers of the basic needs of society which the society itself determines, whereas power-holders are both defining and controlling those needs. Power requires centralization and organs of control; administration permits regional autonomy and a wider range of alternatives for change. These concepts reflect the two opposing "principles of organization" of the post-revolutionary order. The anarchist libertarian ideal of the social revolution is a stateless society organized by the people around the egalitarian administration of food, housing, health and education, while the Marxist ideal is a party dictatorship in the name of a social class which exercises authority over society.

Why did Bolshevism emerge victorious in 1917? Contrary to the view that it had widespread proletarian support, Voline argues that October 1917 was an "unachieved revolution;" Bolshevism succeeded because of the "insufficiency of destruction" of the old order prior to the seizure of power. A revolution cannot occur until the preceding form of political power has been eliminated by the masses. Thus, Lenin essentially reshaped existing power in his own Marxist image, according to Voline, rather than breaking down the bourgeois attitudes and statist institutions of the Old Regime (pp. 198, 205). He was able to do this because of his willingness to "totalitarianize" Russia (p. 357). Highly organized terror and repression were the weapons used against the opposition. In their use of deceitful propaganda. Voline charges that the Bolsheviks 
make the Nazis seem like "modest pupils and imitators" (p. 395, n.). The country has been sealed off from the world in this way, and the actual revolution remains hidden from view.

This description of the "nature of Bolshevism" is one side of the "unknown revolution." The other and more important side concerns the free institutions and experiments of the anarchist opposition, and its mass resistance to Bolshevik authority. Voline spends many pages documenting the creation of non-Bolshevik soviets, committees, and publications across the country in the years immediately following the October Revolution (see especially pp. 267-88). Where possible, Voline supplements his documentation with personal reminiscences. One such case was his 1918 meeting with Bukharin who confessed to Voline that he was against Lenin's policy of a treaty with Germany but that he was powerless to prevent it (pp. 244-45). In another instance he relates several meetings he attended with factory workers which point out Bolshevik intolerance of freedom (pp. 298-301). In one chapter, Voline refutes Bolshevik claims of achievement point by point (pp. $391 \mathrm{ff}$ ), and concludes that Marxism in power has "perverted, chained and castrated the revolution" (p. 422).

The last section of the book is a long account of the "struggle for the real social revolution," which centers on the Kronstadt and Makhnovist rebellions. Interestingly, Voline devotes no attention to the Workers' Opposition faction which also occurred at this time, because he considers these interparty struggles as "family quarrels" (p. 437) and "palace disturbances" (p. 438). He argues that even had this group succeeded, it would not have altered the fundamental structure of Bolshevik state power. Voline's description of the Kronstadt rebellion remains one of the best documentary accounts of the 1921 uprising. His treatment of the Makhnovshchina, however, is entirely based on Arshinov's book, which was unavailable at the time of writing except in the original Russian edition. Voline is far more critical of Makhno than was Arshinov, pointing out his weakness for alcohol, his humiliating treatment of women (p. 705), and his "dictatorial antics of a warrior chief" which fostered a military clique that often made decisions without consulting the responsible administrative bodies (p. 706). Looking back over the entire book, Voline believed that this chapter was "the most important and suggestive of my book;" he urged all who would consider involvement in mass movements in search of the social revolution to read carefully the lessons of this "epic of the Ukrainian masses" and to avoid "the evils which an armed force engenders" (p. 710).

III.

Kanev's book is the most exhaustive Soviet treatment to date of the Bolshevik struggle against anarchism during the revolutionary period, and forms part of the recent revival of Soviet interest in anarchism. (V. V. Komin's Anarchism in Russia and N. M. Pirumova's biography of P. A. Kropotkin are two examples of this interest. Komin's book, published in 1969, was the first serious scholarly study on anarchism published in the U.S.S.R. in thirty years.) The book begins most promisingly by attacking not the ideology of anarchism itself but Soviet studies of anarchism (listed on p.5, n.2) because of their tendency to lump all anarchists into one oversimplified category of "petty bourgeois counterrevolutionaries." Kanev's thesis, quite novel in 
recent Soviet historiography, is that anarchism as an ideology and as "a political tendency" must be distinguished from "anarchism as a mood, as a condition of well-known layers of the masses, as spontaneous elements which grip them" (p. 5). Without entirely disregarding this dominant ideological conception of anarchists, Kanev urges his readers at the same time to see that this mood of elemental revolt which anarchism represents "truly reflects a historical experience" (p. 6). Scholars who research the Communist Party's struggle against anarchism must keep in mind "not only the sum of the evolution of anarchism, but also the complex and contradictory process of its development. Can we really classify each anarchist everywhere and at all times only as counterrevolutionary? Obviously not" (p. 6).

What Kanev is attempting to do is to present anarchism realistically in all its various factions (which include for him the "Soviet anarchists" who cooperated with the regime, and who are unmentioned by Voline and Archinov) and in its separate phases during the period immediately following the October Revolution, to which it was responding in more ways than Soviet historians have admitted. He is criticizing the older Stalinist version of anarchism when he refers to the tendency to view it in terms of "the sum of its evolution." According to that interpretation. the whole of anarchism in Russia was epitomized by the "counterrevolutionary" resistance to Soviet power at Kronstadt and in the Makhnovshchina, which was the "sum" or last stage of the movement's active evolution. The parts were, therefore, judged by the whole, the beginning and middle of "the process of development" seen in terms of its endpoint.

Kanev's documentary materials are impressive. He chooses not to rely heavily on the "more than 240 documents" written by Lenin on anarchism. Instead he makes wide use of not only Bolshevik party sources (some of which are preserved in the highly restricted party archive in the Marx-Lenin Institute), but also of the press, brochures, congress resolutions and memoirs of the anarchists themselves. I can think of no book published in the Soviet Union since the 1930s which quotes so extensively from such materials. Kanev does accomplish part of his ambitious goal, but he is unable to avoid the very ideological battleground he cautioned against. In fact he seems to accept the oversimplified characterization of anarchism which he criticized in his introduction. With no documentation, he approvingly quotes the Stalinist Yaroslavskii's judgment (from a 1939 study) that the anarchists did not engage in "a single significant, serious revolutionary act" during the 1905 revolution. He then turns to the interrevolutionary years and finds the anarchist movement dominated by isolated acts of terrorism and expropriations, with which anarchists "discredited themselves before the masses." However, after the February and October revolutions of 1917, they underwent a period of rebirth which Kanev categorizes into three stages of development: (1) 1917-1918: the zenith of anarchism's influence on the masses, though weakened by internal schisms over ideology; (2) 1918-1921: anarchism becomes "the tool of the White guard counterrevolution" and its influence on the masses recedes; (3) 1921-1922: involvement in the Kronstadt revolt, followed by its "agony as a political tendency" and its disintegration into small sects unconnected to the masses.

Kanev presents the full spectrum of anarchist ideology, with emphasis on both major (anarchist communism, anarchosyndicalism) and minor factions (anarchist individualists, anarchobiocosmists) as well as on the anarchist organizations and press which emerged in these years. He 
claims that despite all this activity, they failed to organize a significant anarchist party because of their rejection of the principle of partiinost' (an untranslatable Russian word which implies political party spirit, values and organizational involvement). He recalls sporadic efforts by Kropotkin and other anarchists to campaign for such a party, but correctly points out that anarchists understood something far broader and looser by the word "party." Similar weaknesses plagued anarchism because of its inability to unite under a single banner; by permitting limitless and conflicting factions, it could not organize a solid constituency. Also, Kanev is persuaded that anarchism was not a working class movement as Western historians have maintained (he cites Joll and Avrich), but was rooted in the less progressive, non-class conscious rural parts of the population. This too deprived it of support on a broader basis.

The confrontational stance of the period begins to blend in with Kanev's own obvious sympathies when he analyzes anarchist attitudes toward the October Revolution. He discusses the anarchist notion of "the third revolution," the slogan of the social revolution which was to follow the bourgeois and socialist-proletarian upheavals. Kanev is critical of the concept of transcending the centralized dictatorship of the proletariat by a decentralized stateless society (pp. 86-98), in contrast to Voline's celebration of such possibilities (see Unknown Revolution. pp. 216-217). More to the point is Kanev's distinction of anarchists and Bolsheviks on "questions of construction of the Soviet state." In this regard, he discerns three primary tendencies among anarchists on the issue of the newly created soviets. One view was that of outright opposition to the soviets, which were seen as organs of Bolshevik authority primarily (the Gordin brothers, Voline, Lev Chemyi). The second group consisted of anarchists who made a distinction between the soviets and Soviet power, and who tried to work with the former while opposing the latter (Iarchuk, Bleikhman, Masal'skii). The last group was made up of anarchists who were willing to cooperate with the Soviet regime and to participate in most existing Soviet organs and councils (Aleksandr Ge, Karelin, Zhelezniakov, Zhuk, Shatov). One of Kanev's more interesting sections is his description of this last group, the so-called "Soviet anarchists." He also provides additional documentation on this trend in the tables he has assembled in the appendix of his volume.

Most anarchists, however, continued to take the revolutionary slogan "all power to the soviets" in a literal manner, which was, according to Kanev, tantamount to "an opportunity for unlimited local autonomy of the soviets" (p. 126). This was in fact true, as Arshinov and Voline show in their books, but Kanev sees this interpretation quite differently. "Soviet democracy," he writes, "has nothing in common with the chaos and disorder preached by the anarchists" (p. 137). He discusses other ideological disagreements, such as the distinction between "Soviet federation" and "anarchist federalism," and between Leninist "democratic centralism" and the "free communism" envisioned by the anarchists. Anarchists challenged the entire notion of law in bourgeois society by seeing it as a means for the minority to enforce its will on the majority. Kanev, however, interprets this to mean "arbitrariness and lawlessness;" he is correct in his assertion that anarchists had no respect for the laws of any state, including those of the Soviet government, but he misses the point of the anarchists' argument here.

In detailing the Communist Party's struggle against anarchism, he analyzes a broad range of issues and institutions, including "the professional movement" (i.e., the professional unions of 
white and blue collar workers), economic policies, and foreign affairs (largely a critique of the anarchists' opposition to the Brest-Litovsk treaty). Kronstadt and the Makhnovshchina are treated as part of the counterrevolution against Soviet power led by the White armies: Makhno's forces are characterized as "anarcho-bandits" whose liquidation saved the country from the disaster of monarchist or bourgeois restoration (p. 373). Voline and Arshinov, it should be recalled. argued that Makhno ironically saved the Bolshevik revolution from disaster by defeating Denikin and Wrangel in the southern campaign before the Red Army seriously entered the battle, but that is another of the many points of dispute in the unending controversy.

One of the permanent aspects of this ideological confrontation is the defensive position felt by each side. Arshinov felt compelled to respond to Bolshevik charges of Makhno's alleged antiSemitism. Voline defended against charges that the anarchists never created institutions capable of survival, and Kanev is not immune to this posture either. His last chapter is essentially an argument against anti-Bolshevik charges by anarchists, and interpretive disagreements with Western historians. The most common error he finds is the belief that anarchism as a whole was liquidated in 1921 after the suppression of Kronstadt and the Makhnovshchina. The lightly veiled defensiveness can be seen when Kanev asserts that the victories over these counterrevolutionary upheavals did not

liquidate anarchism as an ideological-political tendency. Indeed the
Communist Party did not pose before the organs of Soviet power
the task of violent measures to liquidate anarchism as such. The
application of repression against anarcho-counterrevolutionaries did
not spread to all anarchists... The process of the disappearance of
anarchism from the arena of the social life of our country was
complicated and drawn out (p. 374 ).

Kanev goes on to stress that the struggle between them was primarily ideological and was fought out in mass meetings and other public forums. It was a collision of world views in fair and just combat, not the unbridled and one-sided terror depicted by Voline and Arshinov. The fairness and tolerance of Bolshevism even for ideological opponents committed to its destruction can further be demonstrated by some statistics, according to Kanev. In 1922 he calculates there were o33 former anarchists "of various tendencies" accepted into the framework of the party. The Bolsheviks tried to absorb "all true revolutionaries," he states, using a term which Voline and Arshinov also used with a completely different meaning. Further, he indicates that anarchist organizations declined sevenfold between 1918 and 1920 (Table 1, Appendix), suggesting a gradual (not sudden) loss of popular support (rather than violent suppression as alleged by anarchists). Data on the anarchist press shows a similar trend of decline during the same years at about the same rate. The conclusion Kanev draws from this data is difficult to take seriously: the anarchist press was short-lived, he writes, because of the inherent limited appeal of its "sensationalist character," not because it was systematically suppressed. Addressing himself to those Western historians (Guerin, Carter. Joll) who continue to believe that Russian anarchism died a dramatic death in 1921, he cites examples of the survival of anarchist elements in the Soviet Union through the 1920s.

Kanev's conclusion departs from scholarship in approaching the question of the contemporary 
significance of the party's early struggle against anarchism. This experience has "world-wide historical importance." Anarchism remains a threat because of its renewal "on soil foreign to ours." The examples here extend from China in 1958 to Czechoslovakia in 1969, from the Spanish civil war to the French événements of 1968, from Daniel Cohn-Bendit to the BaaderMeinhoff group. Much concern is devoted to the American "New Left," including its "chief theoretician" Marcuse who is quoted as saying that he recognizes anarchism as a "progressive force" (p. 414). "Anarchists, Maoists and Trotskyites" are placed together as the "ultra-left which paralyzes the anti-imperialist and progressive student movement" in America. Thus, Kanev concludes, the struggle of communist Marxists against libertarian anarchists in "contemporary liberation movements" continues to reflect the similar struggle waged in Russia after the October Revolution. Like Voline, he warns us not to ignore these dangerous manifestations of that threatening past.

The ideological confrontation of anarchism and Marxism continues, as these three books make abundantly clear.

Martin A. Miller

Duke University

*c/o New Space Books, 1509 No. Halsted, Chicago, Illinois 60622 or Black and Red, Box 9546, Detroit, Michigan 48202.

Southwest Economy \& Society is a new journal devoted to the critical study of regional development. Those interested in contributing papers, suggestions and criticisms may write: The Editors. Box 4482, Albuquerque, New Mexico 87106.

The Radical History Review is the quarterly journal of the Mid-Atlantic Radical Historians' Organization: it includes essays, book reviews, syllabi, even poetry. Rates are $\$ 5$ low income, $\$ 10$ high income, $50 \notin$ for a sample copy. Send money to Gil Schrank, 107 W. 86th St., NY 10024.

For ten years Radical America has published distinguished work on the history and contemporary analysis of the labor movement, women, black struggles, and working-class life. It has always kept its subscription rates as low as possible; now it faces astronomical increases of $150 \%$ in printing and postage rates. For the first time the future of the magazine is in doubt and an emergency appeal is being made to RA's many friends and subscribers. In order to save RA and preserve it as a vital forum for radical historiography and political debate. the editorial collective is asking for immediate contributions of $\$ 10$ or more. \$25 will purchase a sustaining subscription which includes copies of the many leaflets and pamphlets which RA circulates in addition to the magazine. $\$ 8$ will buy a gift subscription for friend or colleague. Contributions and subscriptions should be sent to Radical America. P.O. Box B, N. Cambridge, Mass. 02140. 